\title{
RESILIENCE OF RELIGIOUS CULTURE IN TRADITIONAL ISLAMIC SOCIETY IN INDUSTRIAL ERA 4.0 IN EAST JAVA
}

\author{
Ishomuddin \\ Professor of Sociology of Islamic Society \\ University of Muhammadiyah Malang \\ ummishom@gmail.com
}

\begin{abstract}
The Islamic community in East Java is dominated by traditional Islamic community groups. They are the basis of the Nahdlatul Ulama (NU) organization. This base spreads from all corners of the village to the cities. Traditional Islamic societies maintain activities that are commonly carried out in NU organizational activities, among others in the form of; manaqiban, diba'an, slametan, and tahlilan that have continued to be carried out since now even though the socio-cultural life of the community has changed. These activities are religious traditions that have survived until now. In fact, this activity has become a kind of habit carried out in government institutions, government and private institutions in the community. Based on the background above, it is interesting to conduct research related to Islamic culture and traditions carried out by a group of traditional Islamic societies in the industrial era 4.0 today. This study aims to understand the understanding of traditional Islamic societies in carrying out and maintaining Islamic traditions in today's modern life. This study uses the social definition paradigm, qualitative approach, and by using descriptive analysis and the data analysis strategy uses the method suggested by Miles, Huberman, and Saldana.
\end{abstract}

Keywords: Resilience, Culture, Religion, Islamic Society, Industrial Age 4.0, Traditional 


\section{INTRODUCTION}

In general, the people of East Java are dominated by traditional Islamic community groups. They are the basis of the Nahdlatul Ulama (NU) organization. This base spreads from all corners of the village to the cities. Traditional Islamic societies maintain activities that are commonly carried out in NU organizational activities, among others in the form of; manaqiban, diba'an, slametan, and tahlilan that have continued to be carried out since now even though the socio-cultural life of the community has changed. These activities are religious traditions that have survived until now. In fact, this activity has become a kind of habit carried out in government institutions, government and private institutions in the community. An interesting paradox to note is that in times when people are leading a rational and modern life in the era of globalization and industry 4.0, people still maintain religious traditions which are considered by some other people to be less effective and efficient. Compared to societies in other parts of Indonesia, the East Java Islamic community is a society that still holds strong in its religious traditions, even though they have rationally lived in modern socio-cultural and economic conditions.

Based on the background above, it is interesting to conduct research related to Islamic culture and traditions carried out by a group of traditional people in the industrial era 4.0 today. This study aims to understand the understanding of traditional Islamic societies in carrying out and maintaining Islamic traditions in today's modern life.

\section{LITERATURE REVIEW \\ 2.1 Culture and religious traditions}

Culture (Dutch cultuur, English culture, and tsaqafah, Arabic language) comes from the Latin colere, which means processing, working, fertilizing and developing, especially cultivating land or farming. In terms of this meaning the culture develops as "all human power and activity to cultivate and change nature" (Prasetyo, 1991) Judging from the Indonesian word "culture" comes from the Sanskrit word, budhayah, which is the plural form of Buddhism which means mind or reason. Thus culture can be interpreted as "things that are concerned with reason", (Zoetmulder, 1958) There are other scholars who examine the word culture as a development of cultivation compound words in the form of creativity, intention and taste (Djoyodiguno, 1958; Malinowski, 1960; Roucek \& Warren, 1984; Sadily, 1983; Koentjaraningrat, 1989).

\subsection{Religion and Culture}

Religion in the sense of al-dien, the source is revelation from God, while the source culture is from humans. So religion cannot be incorporated into the cultural environment as long as humans argue that God cannot be included in human creation. What can be a source of culture is its teachings. Atheists generally assume that God is a human creation that arises from his fear. Everything comes from material, so God is also the result of the development of the material of human reason. By this group religion is seen as a branch of culture, because religion is a way of thinking and feeling in life a social unity concerning relationships with the Almighty. This religion can be termed "cultural religion", such as; animism, dynamism, naturalism (all-natural), spiritualism (all-soul), Kong Hucu religion, Sinto religion, even Hinduism and Buddhism are also included in this category.

For people who are godly, the opposite is true. According to them, this universe is God's creation. Thus religion can influence the creation of culture and even in the power of religious interpretation can also create changes in society. Therefore religion is expected to always be understood in harmony with all social changes that have been positive for human 
life in order to create their culture. This is the challenge of religious people, especially Muslims. For this reason, in this discussion, the author tries to give an overview of the condition of society, especially the Indonesian people in the 21 st century, which deals with religion and culture.

The $21^{\text {st }}$ century is a continuation of the ongoing process of modernization and engulfing all social systems in all nation-states in the world. Modernization has brought much progress. In modernity there is a synthesis of various dimensions of change, for example there are those that emphasize population increase, the rise of the city, and the increase of "impersonality". In modern society, prioritized values are usually characterized by secularism, many sub-cultures, and counter-cultures. While the dominant norms are various moral significance and high tolerance for "diversity". In addition, religion will weaken along with the rise of science. Likewise the plurality of religions will expand. Peter Berger once put forward the characteristics of modernization, namely the collapse of small, traditional communities, the expansion of personal choices; increasing social diversity; and future orientation and increased awareness about time.

Sociology thinkers have put forward a futuristic view of the style of the future society contaminated by this modernization. For example, Tonnis, who predicted that he would lose the community, Durkheim who emphasized the division of labor, and Weber was more focused on rationalization. All these views show that the transformation of various aspects of life is an integral part of modernity or modernization of a nation.

The problem that arises for the Indonesian nation is whether with modernization, or the narrowing down of industrialization, which will intensify later the noble values can be maintained so that the Indonesian nation can be at the same time modern nations, but still rests on a clear identity. Or would the Indonesian nation be a completely new society by tracing the style of foreign society that shaped modernity that has been widely used by the community so far. The Indonesian people must learn a lot from the experiences of other countries, such as the success of the Netherlands in the 17th century and Japan in the 20th century which was driven by the existence of a market economy, absence of doctrinal orthodoxy, rigidity, freedom of discovery, belief in the possibility of progress, rationalism who opposed old customs, religious dogma and traditional folklore.

Judging from the interests of the nation's pragmatics in the future, it is clear that the Indonesian nation is required to always be ready to accommodate all new developments. Sociological studies show that responding to change means changing one's own social priorities, the education system, patterns of consumption and savings, and even changing basic beliefs about individual relationships with society. Where is the dynamic element that will spur society to eradicate poverty, backwardness and ignorance? This question should be raised, considering that so far the Eastern nations have often been called soft society and have no work ethic that supports economic growth. Therefore the main problem of the Indonesian people in the socio-cultural field is to maintain the integrity of the nation while looking for the cultural foundation of the nation's development in the future.

National unity needs to be emphasized so that community diversification does not imply destabilizing the nation's integration. Meanwhile, the cultural foundation is expected to be able to provide positive responsiveness without having to pawn the personality of the nation with all new-foreign cultural patterns that do not necessarily support the preservation of positive original values. The independence of the nation is also very dependent on economic strength and the ability of the Indonesian nation to mobilize human resources in all programs and activities while maintaining unity and unity. As a plural prey, ethics of togetherness and social solidarity also need to be cultivated in all human relations, (Karim, 1997). 
Judging from these needs, the authors argue that from religion, especially Islam, we will get these two answers, if Muslims have the ability to explore valuable "pearls" that exist in the treasures of Islam. Are not the social experts themselves stating that the responsiveness of the nation to change usually comes from social attitudes, religious beliefs and culture? Therefore, religion must be given a function commensurate with its position as a transcendental clue from God. The future resilience of the nation relies heavily on religion. Religion is expected to be an element of the cohesion of the people and at the same time provide fresh breath while providing all aspects of life.

\subsection{Resilience}

According to Reivich and Shatte (2002), resilience is the capacity to respond in a healthy and productive manner when facing difficulties or trauma, where it is important to manage the stresses of everyday life. Resilience is a set of thoughts that makes it possible to seek new experiences and view life as progress. Resilience produces and maintains a positive attitude to explore. Individuals with good resilience understand that mistakes are not the end of everything. Individuals take meaning from mistakes and use knowledge to achieve something higher. Individuals galvanize themselves and solve problems wisely, fully, and energetically.

Connor \& Davidson ( 2003) say that resilience is a person's quality in terms of the ability to deal with suffering. Block \& Kremanin Xianon \& Zhang (2007) states that resilience is used to express individual capabilities to survive and be able to adapt to stressful situations and experience suffering. Resilience will be related to the following: (a) Personal competence, high standards and tenacity. This shows that someone feels as a person who is able to achieve goals in situations of setbacks or failures, (2) Believe in yourself, have a tolerance for negative affect and strong / strong in dealing with stress. This is related to calm, fast coping with stress, thinking carefully and staying focused even when facing problems, (3) Accept changes positively and can make a secure relationship with others. This relates to the ability to adapt or be able to adapt if facing change, (4) Control/self-control in achieving goals and how to ask for or get help from others, (5) Spiritual influence, which is sure to believe in God or fate.

Factors that influence resilience according to Southwick (2012) are: (1) Social support, in the form of community support, personal support, familial support and the culture and community where the individual lives, (2) Cognitive skills, including intelligence, how to solve problems, ability to avoid self-blame, personal control and spirituality, (3) Psychological resources, namely internal locus of control, empathy and curiosity, tend to seek wisdom from each experience and are always flexible in every situation.

Based on the description above, it can be concluded that resilience is the capacity of individuals, to adapt to the situation, by responding in a healthy and productive way to improve themselves, so that they are able to face and overcome the pressures of everyday life.

\section{METHOD}

In accordance with the objectives and unit of analysis, this study uses the social definition paradigm. (Ritzer, 1992; 1988; 2012). Exemplar of this paradigm is Weber's work on social action and Talcott Parsons regarding social action. Weber's work helps direct attention to social definitions in the way that social actors define their social situations and the effects of social definitions in maintaining actions and interactions.

This study uses a qualitative approach. According to Denzin and Lincoln (1994), the qualitative approach prioritizes in-depth interviewing and observation techniques. 
Observation is a typical method of the social definition paradigm. The data obtained are primary and secondary data. Primary data was obtained using interview guideline instruments prepared for informants that were relevant to data needs, namely, first, the Muslim community members who were active in the NU organization and at the same time were party administrators. Secondly, the NU Muslimat Management became the legislature both at the district and provincial levels. While secondary data is data in the form of documents or information written or printed.

Data analysis is done by applying analytical methods that are commonly used in field research. In this case the researcher agrees with the steps written by Babbie (2014), as follows: (a) data analysis in field research is conducted intertwined with the process of observation, (b) Trying to find similarities and differences with social symptoms observed, namely finding the behavior of Muslim NU citizens or normative standards that apply universally within the broader scope of the social system, (c) forming a taxonomy of behavior with regard to observed social phenomena, (d) arranging tentatively theoretical propositions, with regard to relationships between categories that are developed or generated conclusions, (e) Make further observations of behaviors related to temporary theoretical propositions to produce conclusions, (f) Evaluate temporary theoretical propositions to produce conclusions, (g) To prevent conclusions subjectively, efforts are made to develop intersubject though discuss with others and maintain social sensitivity and awareness as a researcher. The collected data was analyzed using an analysis strategy that is an interactive model by Miles, Huberman, and Saldana (2014).

\section{DISCUSSIONS}

After the data is collected, this research produces several things which can be discussed below: The Islamic tradition that has been carried out by traditional groups or communities is a legacy of the previous Islamic community that needs to be done because it has benefits in life. Although it is certainly difficult to trace since when and from where the Islamic tradition began, some say the tradition came since the guardians in Java spread Islam in Javanese land, but the Islamic community generally benefited from the Islamic tradition for all activities that have vertical values, divinity and horizontal values, humanity. On the basis of this kind of understanding, most traditional societies continue to perform as a form of obedience in religion.

The Islamic tradition carried out by traditional groups or communities is to provide benefits and is believed to be associated with inner satisfaction and able to calm life in the attacks of modern culture. There are no activities carried out by the Islamic community that are more beneficial and calming the mind than the activities of tahlilan, manaqiban, selamatan, and other religious rituals. Thus the activities of religious traditions do not take into account the time and place and conditions of any society, traditional or modern. The power of resilience of this activity is very strong because it has spiritual power for the people who do it.

Islamic traditions carried out by groups or traditional societies are considered to have social values in life; intimacy, solidarity, togetherness, peace, which is woven in religious activities in the form of Islamic tradition. Social values in the activities of religious traditions provide the most felt benefits in life. The community can unite and have the same interests and goals in life. By means of such activities in the form of Islamic traditions, the community does not feel afraid otherwise they feel calm in facing the challenges and tests of life.

Islamic teachings related to ritual piety are actually regulated in Islam, namely "Pillars of Islam" which must be done by every believer of Islam. But in practice, they still feel the need to look for or add to activities that have a purpose to get closer to God in other 
ways. Other methods were created by the Sufis known as "tariqat" or "path / method". According to them, it is not enough that Islam is carried out or practiced only through "pillars of Islam", but other ways are needed to more quickly connect with God, including salvation, tahlilan, manaqiban, diba'an, etc. as Muslims have done beforehand. This is the reason why the Islamic tradition is maintained even if they live in conditions that have changed.

The ultimate goal in life is to achieve peace of life and inner peace. The peak of life is the calm that everyone wants to achieve in life. Having lots of assets does not automatically achieve happiness and peace of life. But instead there are people who don't have enough property, they feel calm and calm. Why is that? According to them, this can be obtained because they often do or follow the activities of the Islamic tradition. Islamic tradition in social life has a personal benefit for every actor in the form of calm and serenity in life.

\section{CONCLUSIONS}

From the discussion above, it can be concluded that the activities of Islamic tradition carried out by traditional communities have the following values: (1) Religious traditions are inherited from the ulama, (2) Religious traditions are directly felt spiritually, (3) There are values humanitarian and social values, (4) Other methods of getting closer to God, (5) Islamic tradition as a means of achieving peace of life. These five things are the reasons for traditional societies to maintain religious traditions (Islam) even though they have lived in a modern era and their socio-cultural life has advanced. 
Proceeding ICOGISS 2019

Page 795-801. ISBN: 978-602-6 988-75-1

Web Jurnal Online: jurnal.unmuhjember.ac.id

By: Ishomudin

Resilience Of Religious Culture In Traditional Islamic Society In Industrial Era 4.0 In

East Java

\section{REFERENCES}

Prasetya, Joko Tri dkk. 1991. Ilmu Budaya dasar, Jakarta, Rineka Cipta.

Zoetmulder, P.J., 1958. Cultuur, dikutip Koentjaraningrat, dalam Pengantar Antropologi, Jakarta, Aksara Baru.

Djoyodiguno, M.M. 1958. Azas-azas Sosiologi.

Malinowski, Bronislaw. 1960. A Scientific Theory of Culture and Other Essas, a Galaxy book,

New York Oxford University Press.

Roucek dan Warren. 1984. Pengantar Sosiologi ( Terjemahan), Jakarta, Bina Aksara.

Sadily, Hasan. 1983. Sosiologi Untuk Masyarakat Indonesia, Jakarta, Bina Aksara.

Koentjaraningrat. 1989. Pengantar Ilmu Antropologi, Jakarta, Aksara Baru.

Karim, M. Rusli. Menciptakan Trilogi Baru Pembangunan, Jawa Pos, 27 Januari 1997.

Notowidagdo, Rohiman. 1996. Ilmu Budaya Dasar, berdasarkan Al-Qur'an dan Hadits, Jakarta, Rajawali.

Reivich, K. and Shatté, A. 2002. The Resilience Factor: 7 Essential Skills for Overcoming Life's Inevitable Obstacles. Broadway Books.

Connor, K.M., \& Davidson, J.R.T. 2003. Development of a new resilience scale: The Connor-Davidson resilience scale (CD-RISC). Depression and Anxiety, 18(2), 7682. doi: $10.1002 /$ da. 10113

Xianon\&Zhang, Yu, X \& Zhang. J. 2007. Factor Analysis and Psychometric Evaluation of The Connor-Davidson Resilience Scala (CD-RISC) with Chinese People. Journal of Social Behavior and Personality. 2007. 35 (1), 19-30.

Southwick S. M, Charney D. S. 2012. Resilience: The science of mastering life's greatest challenges. New York: Cambridge University Press; 2012.

Ritzer, George. 1992. Sosiologi Ilmu Pengetahuan Berparadigma Ganda, Penyadur, Alimandan,

Jakarta, Rajawali Press.

Ritzer, George. 1988. Sociological Theory, Second Edition, New York, Knopf.

Ritzer, George and Douglas J. Goodman. 2012. Teori Sosiologi Modern (edisi revisi). Yogyakarta, Kreasi Wacana.

Denzin, Norman K. \& Lincoln, Yvonna S. 1994. Handbook of Qualitative Research. Thousand Oaks London : Sage Publications.

Babbie, Earl. The Basics of Social Research (6th ed.). Belmont, California : Wadsworth Cengage. pp. 303-04, 2014

Miles, Matthew B. \& Huberman A.M., Johnny Saldana. 2014. Qualitative Data Analysis: An Expanded Sourcebook (edition 3), Thousand Oaks, CA: SAGE. 